\title{
PENERAPAN MODEL SINEKTIK DALAM PEMBELAJARAN SEJARAH UNTUK MENINGKATKAN KETERAMPILAN BERPIKIR KREATIF SISWA
}

\author{
Hani Farahdiyana \\ Program Studi Pendidikan Sejarah FKIP Universitas Lambung Mangkurat \\ Banjarmasin \\ Email: 1710111120005@mhs.ulm.ac.id
}

\begin{abstract}
Abstrak: Dalam pembelajaran Sejarah hendaknya tidak mematikan kreatifitas dan memaksa peserta didik untuk menghafal isi buku ataupun fakta dalam buku teks. sudah saatnya pembelajaran Sejarah diajarkan dengan cara yang berbeda, kebekuan pembelajaran yang terjadi seringkali dikarenakan rendahnya kreatifitas dalam pembelajaran sejarah. Sebagai akibatnya peserta didik seringkali merasakan bosan dalam pembelajaran dan hal ini menjadi faktor utama yang akan dihadapi guru dalam mengajarkan sejarah dan peserta didik dalam belajar sejarah.

Pengunaan model dalam sebuah pembelajaran sangat berpengaruh terhadap hasil kemampuan peserta didik dalam belajar disekolah. Agar tercipta pembelajaran yang aktif di kelas antara peserta didik dengan guru. Guru dapat menggunakan model Sinetik dalam pembelajaran Sejarah untuk meningkatkan keterampilan peserta didik agar dapat berpikir kritis, kreatif dan peserta didik mudah memahami materi yang diajarkan.
\end{abstract}

Kata Kunci: Pembelajaran Sejarah, Metode Sinektik, Berpikir Kreatif 


\section{PENDAHULUAN}

Pembelajaran yang dilakukan oleh guru harus mampu mengubah strategi pembelajaran yang berlandaskan paradigma teaching menjadi strategi pembelajaran kreatif berlandaskan paradigma learning. Paradigma learning terlihat dalam empat visi pendidikan menuju abad ke-21 versi UNESCO, yaitu learning to know, learning to do, learning to live together, dan learning to be.

Untuk dapat mewujudkan paradigma pembelajaran tersebut, pendidik dan tenaga kependidikan berkewajiban: (a) menciptakan suasana pendidikan yang bermakna, menyenangkan, kreatif, dinamis, dan dialogis; (b) mempunyai komitmen secara profesional untuk meningkatkan mutu pendidikan; dan (c) memberi teladan dan menjaga nama baik lembaga, profesi, dan kedudukan sesuai dengan kepercayaan yang diberikan kepadanya. (Melisa Prawitasari, 2015: 145)

Pemilihan model pembelajaran merupakan salah satu upaya untuk merangsang keaktifan dan kreativitas peserta didik agar dapat belajar dengan lebih baik. Salah satu model pembelajaran yang dapat digunakan untuk mengembangkan kreativitas siswa adalah model sinektik (synectics). Sinektik merupakan model yang dapat diterapkan dalam semua bidang kurikulum untuk meningkatkan kreativitas baik secara individual ataupun kelompok. Sinektik akan membawa siswa pada usaha pengembangan pola pikir metaforis sebuah pondasi berpikir kreatif. Model Sinektik (Joyce, 2010: 269) berorientasi meningkatkan kemampuan pemecahan masalah, ekspresi kreatif, empati dan wawasan dalam hubungan sosial. (Dalam Dodi Maulana, 2014: 2)

Sekolah sebagai lembaga pendidikan formal dituntut mampu memberikan pembelajaran bermutu kepada peserta didik. Dalam hal ini, seorang guru dituntut berperan aktif dalam menciptakan proses belajar pembelajaran yang efektif. Pembelajaran akan menjadi efektif jika siswa aktif terlibat dalam pembelajaran tersebut.

Mata Pelajaran Sejarah sampai saat ini masih dianggap peserta didik sebagai pelajaran yang membosankan, hal ini dikarenakan model pembelajaran yang digunakan oleh guru tidak bervariasi. Pembelajaran yang dilakukan seringkali hanya berpusat pada guru saja, dimana guru hanya menyajikan pembelajaran dengan metode ceramah dan peserta didik hanya memperhatikan dan mendengarkan guru saja. 


\section{PEMBELAJARAN SEJARAH}

Menurut Skiner, pada saat orang belajar responnya menjadi kuat, apabila ia tidak belajar responnya menjadi turun. Dalam belajar ditemukan kesempatan terjadinya peristiwa yang menimbulkan respons belajar, respons pembelajaran dan konsekuensi yang bersifat menguatkan respons tersebut. Jadi, ketika seseorang belajar maka ia sedang melatih responnya sehingga pemikirannya akan tajam, seperti halnya pisau yang selalu diasah dengan pisau yang jarang atau bahkan tidak pernah diasah, maka akan terasa perbedaan ketajamannya. Belajar sangat penting bagi perkembangan akal manusia, belajar tidak hanya dilakukan oleh anak-anak yang sedang sekolah tetapi orang dewasa pun harus tetap belajar walaupun tempatnya bukan di dalam kelas, bahkan ada istilah pendidikan sepanjang hayat (PSH) itu artinya belajar seumur hidup. (Hamdani, 2010: 17)

Pembelajaran sejarah adalah proses dimana seseorang atau sekelompok orang melakukan aktivitas belajar-mengajar, didalamnya memuat pelajaran tentang kehidupan manusia di masa lampau dalam bentuk peristiwa, dilakukan dengan cara komunikasi dua arah sehingga pesan/nilai dari sebuah peristiwa tersebut dapat tersampaikan.

Menurut I Gde Widja (1989: 23) Pembelajaran sejarah adalah aktivitas belajar-mengajar, didalamnya memuat pelajaran tentang peristiwa masa lampau yang berkaitan erat dengan masa kini, sebab dengan kacamata masa kini kita mampu mempelajari masa lampau. I Gde Widja juga berpendapat bahwa membelajarkan sejarah tidak semata hanya terkait fakta-takta dalam ilmu sejarah namun juga memperhatikan tujuan dari pendidikan pada umumnya, yaitu untuk mencapai kompetensi yang terdiri atas kognitif, afektif, dan psikomotorik seperti yang telah disampaikan oleh Fathurrohman. (Heri \& Akmal, 2019: 27-28)

Pembelajaran sejarah sebaiknya lebih diarahkan untuk rekonstruksi nilainilai karakter melalui cerita sejarah. Dalam kegiatan pembelajaran fokus utama kegiatan pembelajaran bukanlah ekspositori terhadap guru akan tetapi sebisa mungkin lebih ditekankan untuk inquiri. Peserta didik harus diarahkan untuk menemukan nilai-nilai karakter, dan selanjutnya mengaplikasikannya dalam konteks kekinian. (Heri, 2014: 37). Pembelajaran sejarah diharapkan dapat membangun kesadaran, pengetahuan, wawasan, dan nilai berkenaan dengan lingkungan tempat diri dan bangsanya hidup. Pembelajaran sejarah mempunyai peranan dalam upaya pembentukan karakter bangsa dan menanamkan nilai budaya. (Mustika Zahro, 2017: 2) 


\section{MODEL SINEKTIK}

Model sinektik pertama kali digagas oleh William Gordon pada tahun 1961. Model ini dikembangkan dari beberapa asumsi tentang psikologi kreativitas, asumsi pertama dengan membawa proses kreatif menuju kesadaran kita dapat secara langsung meningkatkan kreatifitas kreatif secara individu maupun kelompok. Asumsi kedua komponen emosional lebih penting daripada intelektual. Asumsi ketiga unsur-unsur emosional, irasional harus dipahami dalam rangka meningkatkan kemungkinan sukses dalam situasi pemecahan masalah. (Suntini, 2016)

Gordon menegaskan metode sinektik dalam empat gagasan inti yang menampilkan perubahan konvesional tentang kreatifitas. Pertama, kreativitas penting di dalam melaksanakan aktivitas sehari-hari. Kedua, proses kreatif tidak sepenuhnya merupakan hal yang misterius. Banyak aspek pada kreatif yang dapat dijelaskan,serta dapat memungkinkan bagi seseorang untuk mengarahkan dirinya sehingga mampu mendorong berkembangnya kreatifitas. Ketiga, temuan tentang kreatif berlaku sama pada berbagai bidang, baik seni, ilmu pengetahuan, engginering yang dicirikan dengan kesamaan proses intlektualnya. Keempat, bahwa dalam kelompok tidak berbeda. (Utami, 2019: 3)

Prosedur-prosedur Sinektik juga dapat diterapkan pada semua bidang kurikulum Prosedur-prosedur ini dapat dihubungkan dengan diskusi guru bersama peserta didik dalam kelas dan pada materi-materi yang dibuat guru untuk peserta didik. Hasil aktivitas sinektik tidak harus selalu ditulis. Hasil itu juga dapat dilisankan atau hasil tersebut dapat berbentuk aktivitas-aktivitas bemmain peran Misalnya, ketika menggunakan sinektik untuk melihat masalah-masalah sosial atau perilaku, ingin memberitahukan perilaku situasional sebelum dan sesudah aktivitas sinektik, serta menganmati penubahan-perubahan. Hal ini menarik dilakukan untuk memilih gaya-gaya ekspresif yang berbeda dengan topik awal, seperti meminta peserta didik melukis gambar tetang kerugian atau diskriminasi. Konsepnya abstrak, tetapi gaya ekspresinya harus konkret (Joyce dan Weil, 2003:246).

Model pembelajaran sinektik dalam pembelajaran Sejarah dapat melatih siswa untuk berfikir kreatif dan memudahkan siswa dalam mehami konsep-konsep. Model ini banyak menggunakan analogi, dengan membuat analogi siswa akan lebih mudah untuk memahami konsep, selain itu analogi yang dibuat juga akan memudahkan siswa memahami hubungan antar konsep, peristiwa atau fakta. Contoh penerapan model ini dalam pembelajaran sejarah: 
a. Langkah 1 Deskripsi kondisi saat ini

Aplikasi; guru meminta siswa mendeskripsikan fakta, situasi sesuai tema pembelajaran, misalnya "Pentingnya Persatuan dalam Perjuangan pada Masa Kemerdekaan"

b. Langkah 2 Analogi langsung

Aplikasi; siswa membuat beberapa analogi tentang persatuan, misalnya: analogi pertama, persatuan dengan sapu lidi analogi kedua, persatuan dengan sekelompok semut analogi ketiga, persatuan dengan tali nylon dan seterusnya setelah membuat analogi tersesbut siswa memilih salah satu analogi yang akan dideskripsikan

c. Langkah 3 Analogi personal

Aplikasi; siswa yang telah memilih salah satu analogi kemudian menganalogikan dirinya sesuai analogi yang dipilih, misalnya; siswa memilih analogi sapu lidi. Siswa mengumpamakan diri sebagai bilah lidi yang tidak mampu membersihkan kotoran jika bekerja sendiri.

d. Langkah 4 Konflik padat

Aplikasi; siswa menggunakan deskripsi yang mereka buat terhadap diri mereka sendiri dan mengusulkan konflik (konflik batin atau konflik sebenarnya). Misalnya; betapa tidak nyamannya ketika menjadi sebilah lidi, di satu sisi ingin berguna dengan cara membersihkan kotoran tapi disisi lain tidak mempunyai kekuatan untuk malakukannya.

e. Langkah 5 Analogi langsung

Aplikasi; siswa membuat dan memilih analogi lain sesuai konflik padat yang dibuat, misalnya:

Bilah lidi Berjuang sendiri

Rapuh Mudah dikalahkan

Tidak berdaya Kurang kekuatan melawan penjajah

Banyak lidi menjadi sapu Berjuang bersama menjadi kuat

f. Langkah 6 Pengujian kembali tugas awal

Aplikasi; siswa diminta untuk mendeskripsikan kembali sesuai tema awal dengan menggunakan analogi terakhir atau semua analogi yang telah dibuat dan kemudian mengambil makna atau hikmah dari persatuan sebagai bangsa Indonesia. (Heri, 2014: 104) 
Model pembelajaran sinektek juga memiliki Kelebihan dan kekurangan menurut Sakdiahwati (2008:167) yaitu sebagai berikut:

a. Kelebihan

1. Model ini bermanfaat untuk mengembangkan pengertian baru pada diri peserta didik tentang suatu masalah sehingga dia sadar bagaimana bertingkah laku dalam situasi tertentu

2. Model ini bemanfaat karena dapat mengembangkan kejelasan pengertian dan intemalisasi pada diri peserta didik tentang materi baru

3. Model iri dapat mengembangkan berpikir kreatif, baik pada diri peserta didik maupun guru.

4. Model ini dilaksanakan dalam suasana kebebasan intelektual dan kesamaan martabat antara peserta didik.

5. Model ini membantu peserta didik menemukan cara berpikir baru dalam memecahkan suatu masalah.

b. Kelemahan

1. Sulit dilakukan oleh guru dan peserta didik yang sudah terbiasa menggunakan cara lama yang menekankan pada penyampaian infomasi.

2. Model ini menitik beratkan pada berpikir reflektif dan imajinatif dalam situasi tertentų, maka kemungkinan besar peserta didik kurang menguasai fakta-fakta dan prosedur pelaksanaan atau keterampilan

3. Kurang memadainya sarana dan prasarana pendidikan di sekolah-sekolah.

Dari pendapat tersebut maka dapat disimpulkan bahwa kekurangan dari model sinektik ini yaitu sarana dan prasarana yang ada di sekolah harus lengkap, apabila hal tersebut tidak ada maka penyampaian materi ajar deng menggunakan model sinektik kurang optimal untuk dilakukan. (Dalam Salis, 2017: 25)

Dan kelebihan dari model pembelajaran ini adalah, guru akan lebih mudah menyampaikan konsep kepada siswa dengan cara yang mudah dimengerti. Akan tetapi model ini memang menuntut guru dan siswa untuk berfikir kreatif dalam pembelajaran. Penggunaan model ini juga dapat menghilangkan pandangan bahwa materi sejarah terlepas dari realita kehidupan masa kini. (Heri, 2014: 105)

\section{PENUTUP}

Mata Pelajaran Sejarah sampai saat ini masih dianggap peserta didik sebagai pelajaran yang membosankan, hal ini dikarenakan model pembelajaran yang digunakan oleh guru tidak bervariasi. Pembelajaran yang dilakukan seringkali hanya berpusat pada guru saja, dimana guru hanya menyajikan pembelajaran 
dengan metode ceramah dan peserta didik hanya memperhatikan dan mendengarkan guru saja. Agar tercipta suasana baru dalam pembelajaran dikelas yang dapat melibatkan keaktifan dan kreatifitas peserta didik, guru dapat menerapkan model pembelajaran Sinektik.

Model pembelajaran sinektik dalam pembelajaran Sejarah dapat melatih siswa untuk berfikir kreatif dan memudahkan siswa dalam mehami konsep-konsep. Model ini banyak menggunakan analogi, dengan membuat analogi siswa akan lebih mudah untuk memahami konsep, selain itu analogi yang dibuat juga akan memudahkan siswa memahami hubungan antar konsep, peristiwa atau fakta.

\section{DAFTAR PUSTAKA}

Susanto, H (2014). Seputar Pembelajaran Sejarah; Isu, Gagasan Dan Strategi Pembelajaran. Aswaja Pressindo.

Susanto, H., \& Akmal, H. (2019). Media Pembelajaran Sejarah Era Teknologi Informasi (Konsep Dasar, Prinsi Aplikatif, dan Perancangannya).

Hamdani. (2010). Srategi Belajar Mengajar. Bandung: Pustaka Setia.

Joyce, B, Weil, M, \& Calhoun E. (2003). Model of Teaching (Model Model Pengajaran Edi Keenam). Yogyakarta: Pustaka Pelajar.

Prawitasari, M. (2015). Metode Pembelajaran Hypnoteaching Melalui Mind Mapping dalam Pembelajaran Sejarah (Studi Pada Siswa Kelas XI IPS SMA PGRI 6 Banjarmasin).

Zahro, M. (2017). The implementation of the character education in history teaching. Journal Historica, 1, 5-12.

Maulana, D. (2014). Efek Model Pembelajaran Sinektik Berbasis Peta Pikiran Dan Kreativitas Terhadap Hasil Belajar Siswa Kelas X Mia Sma Negeri 1 Babalan Kabupaten Langkat Ta 2013/2014 (Doctoral Dissertation, Unimed).

Suntini, S. (2016). Penggunaan Model Sinektik Untuk Meningkatkan Kemempuan Menulis Pada Pembelajaran Wacana Naratif Siswa Kelas XI SMK Muhammadiyah Jalaksana Tahun Ajaran 2014/2015. FON: Jurnal Pendidikan Bahasa dan Sastra Indonesia, 9(2). 
Utami, N. H. A. (2019). Pengaruh Penggunaan Metode Sinektika Dalam Kompetensi Menulis Cerpen Pada Siswa Kelas Xi Smk Negeri 1 Palembang (Doctoral Dissertation, Universitas Muhammadiyah Palembang).

Maulidiyah, S. (2017). Penerapan Model Sinektik Guna Meningkatkan Kemampuan Berpikir Divergen Dan Hasil Belajar Peserta Didik Dalam Mata Pelajaran Sejarah Kelas X Mipa 1 Sma Negeri 1 Jember. 